\author{
Aleksei Pleshkov \\ ORCID: 0000-0003-1327-568X \\ Poletayev Institute for Theoretical and Historical Studies in the Humanities, \\ National Research University Higher School of Economics \\ (Moscow, Russian Federation) \\ apleshkov@hse.ru

\section{Jan Surman} \\ ORCID: 0000-0003-1499-3122 \\ Masaryk Institute and Archives of the Czech Academy of Sciences \\ (Masarykův ústav a archiv Akademie věd České republiky) (Prague, Czech Republic) \\ Founding editor of the online platform "History of Science in Central, \\ Eastern and Southeastern Europe" \\ (https://hpscesee.blogspot.com/ | https://www.facebook.com/groups/hps.cesee) \\ jan.surman@gmail.com
}

\title{
Book reviews in the history of knowledge
}

\begin{abstract}
Academic reviewing, one of the communal academic practices, is a vital genre, in which epistemic virtues have been cultivated.

In our article, we discuss reviews as a form of institutionalized critique, which historians could use to trace the changing epistemic virtues within humanities. We propose to use them analogously to Lorraine Daston's and Peter Galison's treatment of atlases in their
\end{abstract}

\begin{tabular}{|c|c|c|c|c|c|}
\hline \multicolumn{2}{|c|}{$\begin{array}{l}\text { PUBLICATION } \\
\text { INFO }\end{array}$} & Tien & $\begin{array}{r}\text { e-ISSN 2543-702X } \\
\text { ISSN 2451-3202 }\end{array}$ & 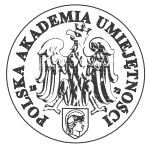 & $\begin{array}{c}\mathbf{6} \\
\text { DIAMOND } \\
\text { OPEN ACCESS }\end{array}$ \\
\hline \multicolumn{6}{|c|}{$\begin{array}{l}\text { CITATION } \\
\text { Pleshkov, Aleksei; Surman, Jan 2021: Book reviews in the history of knowledge. Studia Historiae } \\
\text { Scientiarum 20, pp. 629-650. DOI: } \underline{10.4467 / 2543702 X S H S .21 .018 .14049 .}\end{array}$} \\
\hline \multicolumn{3}{|c|}{$\begin{array}{l}\text { RECEIVED: } 03.10 .2020 \\
\text { ACCEPTED: } 14.07 .2021 \\
\text { PUBLISHED ONLINE: } 13.09 .2021\end{array}$} & $\begin{array}{l}\text { ARCHIVE } \\
\text { POLICY } \\
\text { Green SHERPA / } \\
\text { RoMEO Colour }\end{array}$ & (c) & $\begin{array}{l}\text { Crossref } \\
\text { Similarity Check } \\
\text { Powered by iThenticate }\end{array}$ \\
\hline WWW & \multicolumn{5}{|c|}{ https://ojs.ejournals.eu/SHS/; http://pau.krakow.pl/Studia-Historiae-Scientiarum/archiwum } \\
\hline
\end{tabular}


seminal work Objectivity as a marker of changing epistemic virtues in natural sciences and medicine.

Based on Aristotle's virtue theory and its neo-Aristotelian interpretation in the second half of the $20^{\text {th }}$ century, as well as on its most recent applications in the field of history and philosophy of science, we propose a general conceptual framework for analyzing reviews in their historical dimension. Besides, we contend that the analysis of reviews should be carried out taking into account their historical context of social, political, cultural and media-environment. Otherwise, one may risks presupposing the existence of an autonomous, disconnected community of scholars.

Keywords: reviews, epistemic virtues, communal practices, scientific self, academic genre, future of humanities

\title{
Recenzje książek z zakresu historii wiedzy
}

\begin{abstract}
Abstrakt
Jako jedna z wspólnych praktyk akademickich, recenzowanie akademickie jest istotnym gatunkiem literackim, w którym kultywowane są cnoty epistemiczne.

W naszym artykule omawiamy recenzje jako formę zinstytucjonalizowanej krytyki, którą historycy mogą wykorzystać do prześledzenia zmieniających się cnót epistemicznych w naukach humanistycznych, analogicznie do klasycznej pracy Lorraine Daston i Petera Galisona Objectivity, gdzie atlasy (zawierające zbiory map, wykresów, ilustracji) są używane do omawiania zmieniających się cnót epistemicznych w naukach ścisłych, przyrodniczych i w medycynie.

Opierając się na teorii cnót Arystotelesa i jej neoarystoteliańskiej interpretacji w drugiej połowie XX w., jak również ich zastosowaniu na polu historii i filozofii nauki początku XXI w., proponujemy generalne ramy koncepcyjne do analizy recenzji w ich wymiarze historycznym (a także innych wspólnych praktyk akademickich). Poza tym twierdzimy, że recenzje należy analizować w historycznym kontekście społecznym, politycznym, kulturowym oraz medialnym, aby nie wpaść w pułapkę zakładania autonomicznej, odłączonej od społeczeństwa wspólnoty naukowej.
\end{abstract}


Słowa kluczowe: recenæje, cnoty epistemiczne, wspólne praktyki akademickie, to ̇̇samość naukowca, akademicki gatunek literacki, prayszłosí nauk bumanistycznych

\section{Introduction}

Book review is an academic genre of a long history, and of various functions. They have been functioning since the $17^{\text {th }}$ century ${ }^{1}$, when the genre of printed reviews appeared, up to the online versions nowadays. Unlike the peer-reviews, which have been a matter of both historical and sociological scrutiny, ${ }^{2}$ book reviews are analyzed mostly in anecdotal texts, and often in connection with anniversaries of retirement of notable book review editors. More recently, we can find them in histories of scholarly virtues and vices, as a genre in which virtues were laid out, vices condemned, and thus a model of the scholarly self was constructed $^{3}$. This paper, and the section of Studia Historiae Scientiarum it prefaces, intends to spark interest in reviews as a communal academic practice, becoming a source for understanding the moral economy of modern sciences and humanities in particular.

While it is our intention to promote reviews as a source of new research questions, it is not our intention to discuss all possible directions this research might take. Instead, we focus on the connection between virtues and reviews. While virtues can be considered as booming topic in the history of science, successfully questioning old tropes of the discipline, ${ }^{4}$ we are interested in one particular set of virtues - epistemic ones. ${ }^{5}$ And we acknowledge here and agree with the opinion that epistemic virtues should not be understood in a "strong sense ('only

1 Gael 2012.

2 Just exemplary from the STS point of view Lorenz-Meyer 2018, and from historical Gould 2012.

3 See, for instance, the project "The Scholarly Self: Character, Habit, and Virtue in the Humanities, 1860-1930" and "Scholarly Vices: A Longue Durée History" by Hermann Paul at Leiden University, see esp. Engberts 2019. See also Stoeger 2020.

${ }^{4}$ Two examples of many would be the (alleged) demise of personal aspects in science connected with the onset of technosciences (see Shapin 2008, Eskildsen 2016), the other natural sciences as leading the mathematisation of scholarship (see Krajewski 2016).

${ }^{5}$ On epistemic virtues see Gelhard, Hackler, Zanetti 2019. 
epistemic'), but in a weak one ('epistemic' as one layer of meaning among others)." ${ }^{\prime}$

In the paper, we introduce our idea of connecting book reviews to the discussion on epistemic virtues in humanities, especially by analogy with the discussion in history of natural sciences symbolized by the research on objectivity. ${ }^{7}$ Then, we discuss some examples of book reviews and how their media coverage and social context relate to the virtues they express.

\section{Book reviews and epistemic virtues}

In the presentation given at Poletayev Institute's conference "Academic Revolutions? Understanding conceptual renewal and institutional innovation in the Modern World" (2017), an influential Israeli philosopher of science and the adherent of Karl Popper's ideas, Joseph Agassi, stated that it is the duty of scientists and philosophers "to be critical of our own tradition" [our italics]. The criticism does not presuppose the disrespect to traditions, on the contrary, it demands the respect to mistakes of the others. ${ }^{8}$ According to Agassi, the setting for the benefit of criticism lies at the very foundation of the European philosophical (and scientific) tradition, and it can be found already in Plato's dialogues. In Gorgias, which Agassi referred to, Socrates explains to the sophist from Leontinoi:

I'm asking questions so that we can conduct an orderly discussion. It's not you I'm after, it's to prevent our getting in the habit of second-guessing and snatching each other's statements away ahead of time. It's to allow you to work out your assumption in any way you want to [our italics]. ${ }^{9}$

Whether Agassi, a student of the author of The Open Society and Its Enemies, ignores the specificity of Plato's dialogism, taking the irony of Socrates at face value is not so important. The conclusion that Agassi comes to, while reflecting on Plato is:

\footnotetext{
${ }^{6}$ Creyghton, Huistra, Keymeulen \& Paul 2016; Paul 2019.

7 Daston, Galison 2007.

8 Agassi 2017.

${ }^{9}$ Grg. 454 c (trans. by Donald J. Zeyl).
} 
The main thing to realize, it is when I show you are mistaken, it is not contempt for you, but it is respect for you, it is not hating you, but helping you [...] Criticism is not bostile, but friendly [our italics]..$^{10}$

The definition of 'review' we follow here, is: a genre of academic, literary or art critique. ${ }^{11}$ But the word 'critique' itself gained rich semantics, close to criticism, and some languages, notably Germanic and Slavic, express these both concepts with the same word. Today, in everyday language, 'critique' is understood most often as a negative judgment, which indicates the shortcomings of an object. In the ultimate sense, critique merges with carping here and presupposes a purely subjective reaction. More sophisticated 'critique' involves careful, consistent consideration, the purpose of which is to determine the boundaries and conditions of the very possibility of something. Here, the understanding of critique approaches a fundamentally objective evaluation. The tension between subjective and objective dimensions of critique is essential for understanding reviewing as an academic practice. However, there is another meaning of 'critique', fundamental in the context of our discussion. The original Greek meaning of 'critique' as kritikos or kritikè techne, the ability or art of judgment, pertained primarily to the sphere of practical life. For example, Aristotle considers the art of judgment not as a separate ability or skill of a person, but the foundation that constitutes human beings:

Being a man of understanding and of good or sympathetic

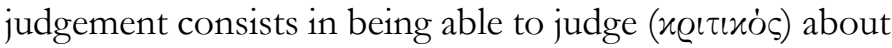
the things, with which practical wisdom is concerned; for what is equitable is the common concern of all good men in their dealings with others [our italics]. ${ }^{12}$

Notions of 'equity' (epieikeia) and 'equitable' (epieikes) in Aristotle are synonymous with 'good' (agathos) and 'benign' (spoudaios) and refer to a specific kindness-humanity. An equitable man is "the man who chooses

10 Agassi 2017.

11 Merriam-Webster defines review, a.o. as "a critical evaluation (as of a book or play)" (https://www.merriam-webster.com/dictionary/review).

12 Arist. EN VI. 1143a (trans. by David Ross). 
and does such acts, and is no stickler for his rights in a bad sense, but tends to take less than his share, though he has the law on his side." ${ }^{\prime 3}$ The ability to judge is a necessary quality of a person, ready to receive less than they have the right, consciously going to self-restrain and even a sacrifice. But for what? For the sake of community, communication, and community affairs. ${ }^{14}$ In the present-day academia, subordinated to the logic of efficiency and the practices of accounting, assessment, and rating, book reviewing can be seen as a too costly and ineffective enterprise. However, if we recall the original meaning of critiquekritikos, it becomes clear why this matter is important. Critique-kritikos, in the ultimate sense, defines what is needed in the community: not only goals and goods but also the way they should be achieved. With regard to reviewing, critique is normative, it determines what science ought to be: not only in the sense of rules and norms, but also in those means of argumentation and rhetoric that it legitimizes. ${ }^{15}$

Our recalling Plato and Aristotle is not accidental. Ancient Greek philosophy gives us an example of the productive interplay of epistemic and ethical dimensions. As French philosopher, Pierre Hadot, puts it:

In the first place, at least since the time of Socrates, the choice of a way of life has not been located at the end of the process of philosophical activity, like a kind of accessory or appendix. On the contrary, it stands at the beginning, in a complex interrelation with critical reaction to other existential attitudes, with global vision of a certain way of living and of seeing the world, and with voluntary decision itself. ${ }^{16}$

13 Arist. EN V. 1137b-1138a (trans. by David Ross).

14 Allen 2004, pp. 153-157.

15 Here, the fundamental importance of the genre becomes apparent. First, reviews are actively present in the educational space, which means they act as a tool for "reflective translation of the rules, requirements and patterns typical for a particular scientific community" (Stepanov 2020, p. 195). Second, review is one of the forms of expert activity, in each case claiming to (re)define both the rules of academic communication and the boundaries of scientific discourse, and thus the very structure of the scientific community. Finally, review is directly embedded in the broader structure of the assessment and diagnosis of scientific knowledge, which means it leaves an imprint on management decisions in the field of science (Stepanov 2016, p. 83).

${ }^{16}$ Hadot 2002, p. 3. 
The heuristic potential of this interplay was brilliantly demonstrated quite recently in Lorraine Daston and Peter Galison's Objectivity, one of the most important books of the $21^{\text {st }}$ century in the field of the history of knowledge. ${ }^{17}$ Here, the concept of objectivity is not dissolved in the pretended self-obviousness of the philosophy of science, but is considered as a specific virtue of the scientific self, cultivated in the research and study practices. With a little help of Aristotle, or, more accurately, with the non-relativistic interpretation of Aristotelian virtue ethics by Martha Nussbaum, ${ }^{18}$ we can propose the general conceptualization to emphasize the importance of the scrutiny of reviews for the history and philosophy of knowledge.

(1) A scientist, in a broader sense of the Latin scientia, i.e., any field of systematized knowledge, is involved in various forms of social activities. Some of them could be more or less accidental, even if they are a part of the everyday working routine: say, in Moscow, almost all researchers use the metro to get to and from work, but it is still an accidental activity for a scientist. Some of these activities contribute to the core of academic life, even if they are quite irregular or unique, such as Rektoratsreden [Rector's address/speech], and could be marked as sustainable forms of scientific interactions. As Daniel J. Hicks and Thomas A. Stapleford put it, following Alasdair MacIntyre, these are the "communal practices": "In a phrase, a communal practice is a complex, collaborative, socially organized, goal-oriented, sustained activity." 19 All of these communal practices have their own goals; they are aimed at achieving particular goods. Probably, it is possible, following Aristotle, to define the most fundamental forms of scientific interactions, "grounding experiences" which are common for any scientist as 'scientist' defined (like experiences connected with mortality, body, pleasure and pain, cognitive ability, etc., proposed by Martha Nussbaum as common for human beings as human beings). ${ }^{20}$ Nevertheless, rather than searching the (un)questionable constants of scientific life, it is more heuristically

17 Daston, Galison 2007.

18 Nussbaum 1998, pp. 32-53. For other possible conceptual moves, still neo-Aristotelian in their character,see e.g., Hicks, Stapleford 2016 and their version of MacIntyre's approach.

${ }_{19}$ Hicks, Stapleford 2016, p. 454.

${ }^{20}$ Nussbaum 1998, pp. 41-42. 
productive to consider the different sustainable and communal forms of scientific interactions ${ }^{21}$ if they have sufficient continual historical depth and sufficient geographical diversity.

(2) The achievement of communal practices' goals presupposes that a scientist should do well in different sustainable forms of scientific interactions. It is possible by means of various virtues. Rosalind Hursthouse and Glen Pettigrove define a virtue as follows:

A virtue is an excellent trait of character. It is a disposition, well entrenched in its possessor-something that, as we say, goes all the way down, unlike a habit such as being a teadrinker-to notice, expect, value, feel, desire, choose, act, and react in certain characteristic ways. To possess a virtue is to be a certain sort of person with a certain complex mindset. A significant aspect of this mindset is the wholehearted acceptance of a distinctive range of considerations as reasons for action. An honest person cannot be identified simply as one who, for example, practices honest dealing and does not cheat. If such actions are done merely because the agent thinks that honesty is the best policy, or because they fear being caught out, rather than through recognizing "To do otherwise would be dishonest" as the relevant reason, they are not the actions of an honest person ${ }^{22}$.

Since communal practices can have different goals at once, it means that participation in this or that practice can cultivate different virtues. Again, it is probably possible to define a kind of leading virtue in the given practice or even a range of practices. However, again, it seems more heuristically productive to talk and discuss constellations of virtues. ${ }^{23}$ For example, considering publication activities, we can distinguish the goods of excellence (internal goods), such as hypothesis justification or refutation of a theory, from the goods of efficiency (external goods), such as getting extra money for publication or promotion. ${ }^{24}$

${ }^{21}$ For example, see discussions in Schnicke 2015; Dhondt 2014; Echterhölter 2012; Dhondt 2011.

22 Hursthouse, Pettigrove 2003.

${ }^{23}$ Pleshkov, Surman 2020, Engberts 2019, Paul 2014, esp. pp. 357-367.

${ }^{24}$ Hicks, Stapleford 2016, pp. 457-460. 
Consequently, we would distinguish various virtues within one practice, e.g., robustness on the one hand and career ambitiousness on the other. Moreover, different researchers can disagree about the goods of the very same practice. ${ }^{25}$

(3) Thus, virtues are not a kind of regulative ideal, nor a postulated abstract value. Virtues are what is repeatedly cultivated in communal practices and becomes a part of a scientist's self. It is not just about shaping of the effective intellectual decisions, like choosing the trending theories, conceptual framework or "hot topics". It is about the self of a scientist ${ }^{26}$. There is the direct link between the virtue and the actual existence of its possessor: to possess virtue means to be in a certain way. In this sense, the virtue is not a habit, neither sentiment or feelings, but the foundation that makes its possessor what they are. Therefore, the virtue determines every action, permeates the entire existence of the self, up to the forming of specific bodily constitution. This is how Hermann von Helmholtz described a contemporary researcher, brought up by the seminar-system:

$[\mathrm{H}] \mathrm{e}$ needs skills, which can be acquired only through repeated attempts and long practice. His senses must be sharpened for certain kinds of observation. For slight differences in form, color, consistency, smell, etc. in the object of investigation. His hand must be trained here to do the work of the smithy, there that of the carpenter, or yet again that of the draughtsman or violinist, or of a lacemaker. ${ }^{27}$

Seminar is a good example of a communal practice, that was used to convey the virtues. Speaking of the seminar as an educational method that legitimizes contemporary universities' connection with the Humboldtian

${ }^{25}$ Ibid., p. 455. See also: Paul 2014, pp. 360-363.

26 The consideration of the scientific self through the prism of the embodied virtues leads to the epistemological category of 'scholarly (or scientific) persona', crucial for 'practical (or performative) turn' in the history of knowledge: "Intermediate between the individual biography and the social institution lies the persona: a cultural identity that simultaneously shapes the individual in body and mind and creates a collective with a shared and recognizable physiognomy" (Daston, Sibum 2003, p. 2). See also: Paul 2014.

${ }^{27}$ Quoted after Daston 1998, p. 79. 
model of university, is a regular rhetorical figure for a historian of ideas. However, taking into account the virtue theory, it is obvious that the practice drastically changed its goals and virtues. For a $19^{\text {th }}$ century German scientists, regardless if physicist or classicist, seminar was the crucial element of the shared sensibility in the unity of Science. ${ }^{28}$ Do we really still see the virtue of corporationism in Science (with a capital 'S') in today's seminars?

This is an open question. Moreover, it seems to us that it is a question of developing a new language. The notions such as objectivity, autonomy, or academic freedom are usually considered unproblematic or self-evident values of science per se. But how do these notions work in scientific practices? The academic freedom of the $19^{\text {th }}$-century German professor, choosing the subject for research and teaching, was provided by specific mechanisms (state-appointed professors, the institute of Privatdozent, etc.). ${ }^{29}$ Is it the same freedom for the $21^{\text {st }}$-century Russian professor, stuck between National Educational Standard, Student's Teaching Quality Assessment, and the necessity to publish in the journals listed in Scopus/WoS databases only? Do any communal academic practices exist that can provide a basis for comparison of these freedoms? The virtue theory approach does not necessarily confute the basic categories of classical philosophy of liberal education. However, it definitely rejects the uncritical parasitizing on its rhetoric. ${ }^{30}$ The virtue theory can be seen as a mediator between ideals and practices in the field of history and philosophy of knowledge $\mathrm{e}^{31}$, between Mertonian-style rigorism of deontological epistemology and very pragmatic (or even malevolent) vision of anthropologically colored microhistory of science. ${ }^{32}$

${ }^{28}$ Daston 1998, pp. 82-83.

${ }^{29}$ Kurennoy 2020, pp. 13-18; on the further life of the idea and mechanism supporting it: Wilholt 2012.

${ }^{30}$ Regarding the related field of the history and philosophy of education see: Readings 1996, pp. 62-64.

31 Van Dongen, Paul 2017, p. 7.

32 See here the critique by Peter Galison: "There seem to be aspects of scientific practice that simply do not reduce to the local. Look too closely at particulars and you won't understand the creation of scientific languages that don't arise in the head of any single researcher. Examine one particular laboratory with too much magnification and you won't see the building up of ways of being a scientist-the scientific persona, 
In the Nicomachean Ethics, Aristotle quite often remarks that there are no names for some of the virtues (and vices) he discusses. He wrote even that

most of these $[\ldots]$ have no names, but we must try, as in the other cases, to invent names ourselves so that we may be clear and easy to follow. ${ }^{33}$

Knowledge is dynamic and it necessitates new and various virtues. ${ }^{34}$ Doing science well is not just declaring these virtues, but they shall be fixed in communal practices. In the history of knowledge, the practice of reviewing is such a communal practice, as it involves a systematic implementation of the norms and languages of science. Thus, a theoretical understanding of reviewing leads us to a better understanding of the practices within the scientific community, and gives us the possibility to thoughtfully improve them.

\section{Historicizing book reviews}

After an attempt to outline the most general elements of our theoretical framework, we would like to turn to some specifications concerning the genre of reviews. ${ }^{35}$ Since the emergence of reviews ${ }^{36}$ and their medium, review journals, reviews were seen as not only texts, in which mistakes or malpractices could be listed, and ways of interpretation challenged. They were also seen as guides to reading publications ${ }^{37}$ and they became an important form of the scientific interaction. As such, they underwent significant changes, depending on the scholarly culture or

changing over time, is not an individual's invention. (For example: Should a scientist be more like an industrialist, a sage, a divine, an artist, or an entrepreneur?) These larger, normative roles, techniques, and methods are not just misunderstood: they are invisible when the view is too close" (Galison 2008, p. 122).

33 Arist. EN II. 1108a (trans. by David Ross).

34 E.g.: Hicks, Stapleford 2016; Paul 2014; Daston, Galison 2007; Daston, Sibum 2003.

35 Much of this reflection comes from the research project "The School of Reviewing" at the higher School of Economics. Moscow. URL: https://www.hse.ru/ review/; for printed results see Pleshkov, Dolgoroukova 2020.

36 For a brief history of reviews see Orteza y Miranda 1996; Munck 2010; Gael 2012.

37 Topham 2013; see also on the history of reviews in this period, e.g. Löffler 2020. 
discipline, ${ }^{38}$ as other forms of social interaction, maneuvering between internal and external expectations. The sustainable forms of scientific interactions are not isolated in any kind of platonic world of ideas: they are incorporated into a fabric of social relations, that is, interconnected with non-scientific practices. To ignore these interconnections is to oversimplify and idealize the history of the genre. Upon expressing the virtues, which can also play other functions and do not have to solely be epistemic ones, as noted above, reviews can also strengthen other values: for instance loyalty or masculinity, as demonstrated by scholars researching the $19^{\text {th }}$ century. ${ }^{39}$ Moreover, the practice of virtues can be manipulated by the specific institutional design or, more generally, by the influence of the concomitant social contexts. As Herman Paul notices:

So how is it that scholarly personae change under the influence of external pressure? Without proposing anything like a covering-law model, or encouraging a behaviorist type of reading desires back in from scholarly practice, I argue that constellations of goods are rooted in constellations of desires, which are susceptible to influence exercised by examples and rewards. Scholarly personae come into being not merely because scholars voluntarily decide to commit themselves to certain constellations of goods, but also because their (institutional) contexts encourage them, sometimes against their best judgment, to conform to new models of scholarly selfhood. ${ }^{40}$

Thus, the reviews are also subject to other constraints that are not linked directly with the epistemic questions. The following sections should offer us some ideas for the future investigation of the epistemic virtues based on examples from the history of reviews.

38 While the historical cross-cultural research on reviews in different cultures and languages is yet to be done, results from contemporary language studies provide noteworthy hints into the different appropriation of the review practice, e.g. Itakura, Tsui 2011; Wang, An 2013. For reflections on changes over time see, e.g., Bilharz 1984. On disciplinary differences, see Hartley 2006.

39 Paul 2019, Paulitz 2018; Schnicke 2015.

${ }^{40}$ Paul 2014, p. 369. 
For example, as Andrei Lihatskiy demonstrated, economic constraints can dictate the review's style, because sharp polemic "sells" a journal better although it may be of lighthearted content. ${ }^{41}$ Thus, the cultivated epistemic virtues could be reshaped by the editor's demands. Such processes could be seen in history repeatedly, as editors, shaping the review policy, may strategically tune it in order to suit particular demands. Thus, we should think of reviews as being also strategic means of active participation in the creation of intended virtues for given communities by fighting off the unwanted approaches. Or else, conversely, gathering reviews, which can support one's approach. ${ }^{42}$ Anyway, reviews are a genre, in which rules of new disciplines can be laid out through the careful practice of distinguishing one's subject of interest. ${ }^{43}$

However, such an influence does not have to be explicit or personalized, but can be a result of accidental circumstances. The example

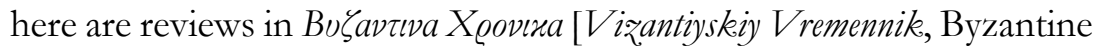
Chronicles], one of the first leading journals on Byzantine studies in the Russian Empire, which was financed by the government and had to be published in the printing house of the Academy of Sciences exclusively. Because the printing house worked quite slowly, the issues were published with severe delay, often a year after being edited. Thus the informative functions of reviews' published there, namely to inform promptly about the release of new books, receded into the background. Therefore, the reviewers writing for the journal focused on more indepth analyses of the literature, strengthening the research function of the review in this way. Thus, sluggishness of the governmental agencies influenced the virtues, cultivated in the practice of reviewing indirectly, shifting the focus from 'informative' to 'meticulous'. ${ }^{44}$

${ }^{41}$ Likhatskij 2018, pp. 111-112.

42 Both approaches can be observed in the nascent French sociology, with the poles of Émile Durkheim's L'Année Sociologique and René Worms' Revue Internationale de Sociologie; see Mosbah-Natanson 2008 and Giddens 1970.

43 Wald Valensky 2010.

${ }^{44}$ See Likhatskij 2020. Here, the case is about virtues of the review, not the virtues of the self. While it seems (from common sense standpoint) that these two come sideby-side, the problem of interconnections between virtues of scholarly products, such as (persuasive) argument, (solid) theory, or (saleable) review, and virtues of scholarly persona, such as ingenuity, robustness, or wit, remains an important theoretical issue (see: Paul 2011). 
Looking at the nineteenth century, we can observe how reviews were involved in the processes of nationalization, maneuvering between epistemic virtues that they were to embody, and employing it in the two important forms. First, reviews of the foreign scholarship in one's own language were supposed to correct the "false" information, or present it to the readers in such way that it suited the prevailing narrative of, for instance, nationalist history or literature. Second, scholars were supposed to write their reviews of national publications in the more accessible languages, like German or French, ${ }^{45}$ and some Frenchlanguage and German-language journals explicitly encouraged such texts to appear. ${ }^{46}$ Here, the meticulousness or 'analyticity' were already in the background, and the informedness prevailed, although more research would be needed to substantiate this statement. It is easy to imagine that the power of presenting colleagues' work to foreign readers, typically held in a higher esteem than the locals, could easily be used to fight petty local conflicts. Interestingly, recent research has indicated that this role of reviews, i.e. bridging scholarly communities and crossing international borders, has significantly diminished over the years, and scholars now review more within their own community, resp. colleagues they are personally acquainted with. ${ }^{47}$

Yet another, but probably more typical, example influencing the reviews, is the governmental censorship. This can be vividly illustrated by the study of Soviet historical periodicals, as done by Sergey Matveev for the historical journals in the 1930s - 1950s. Although the reviews of this period still fulfill the "traditional" virtues of the genre (informedness, analyticity, communicativeness, and openness to discussion, which became a leading epistemic virtue of Stalinism and beyond), a new virtue could be clearly distinguished (let us call it 'ideological robustness'). The reviews become the instruments of ideological critique against the researchers, who did not adhere strictly to the Marxist-Leninist orthodoxy:

In all reviews of this type, there was a collective subject a Soviet scientist, who ought "to be a role model," "to remember the genius book," "to resist temptations,"

\footnotetext{
45 Surman 2014.

46 Ottner 2014, pp. 164-165.

47 Jarrèque et al. 2019.
} 
"to understand the social meaning," "to be guided by the only true Marxist-Leninist method," "in the interests of the entire history of the ancient world," etc. And their counterpart, the Western author, as a rule, "suffered from methodological helplessness," "did not know the basics of the historical materialist method," "did not reach the understanding of the processes," "was a hostage to bourgeois ideology," and sometimes turned out to be a "troubadour of American imperialism," therefore his conclusions were "thoroughly false"

It becomes clear, that in order to talk about reviews as a communal practice, we have to carefully consider them as historical and medial phenomena. Obviously, a function of a review in Historische Zeitschrift is different than the one published online in a platform like H-Soz-u-Kult, and so are the virtues involved. ${ }^{49}$ Nowadays, we experience a process, in which open access scholarly media are blossoming and we might be at the crossroads of what reviews are and will be in the future. ${ }^{50}$ Will they be long detailed analyses, or shorter, informative blurbs? It is also clear that academic politics, in which currently reviews do not count as publications but are growingly seen as a "community service activity," 51 will play a role in this. ${ }^{52}$ However, we should not castigate new scholarly social media for proliferation of the reviews too hastily, and doom the acceleration of scholarly communication for the failing meticulousness. This would be echoing the criticism that reviews as a genre were facing from the very beginning, namely that they are replacing deep-reading

48 Matveev 2018, p. 141.

49 One of the main differences between H-Soz-u-Kult would be that review editors of the platform discouraged direct criticism, which is also mentioned in the official guidelines (http://hsozkult.geschichte.hu-berlin.de/daten/texte/Review Notes HSK Books.pdf, accessed 13.03.2021), whereas in German-language printed (historical) journals such limitation was not in place.

${ }^{50}$ Notably, the most recent discussion on the future of book reviews in humanities is taking place exactly in H-Soz-u-Kult (https://www.hsozkult.de/debate/id/ diskussionen-5234?title $=$ forum-buchrezensionen-in-den-geschichtswissenschaften, accessed 13.07.2021).

51 Päivi, Leppälä 2013.

52 This statement is of course a generalization, as scholarly systems differ. 
with more or less superficial account. ${ }^{53}$ We should rather consider pros and cons, benefits and disadvantages, of the changing reviewing practice and the consequences for the epistemic virtues.

\section{Chapters in outline}

In this special section, we look at different historical periods and put the idea of historicization of the review practice into work.

Alexander Stoeger (Leiden) looks at the practice of reviewing in late $18^{\text {th }}$ century journals in German language, when review-devoted periodicals began appearing in various fields. Backed by anonymity, which was regarded as crucial to assure objectivity, book reviewers saw themselves as tubes of scholarly community, deciding about which vices to support and which to castigate. Upon doing this, they also construed a figure, or persona, of an ideal scholar, often using religious and emotional vocabulary or directly referring to the epistemic virtues that the reviewed scholars embodied.

Christiaan Engberts's (Utrecht) text takes us to the second half of the nineteenth century: a threshold when the two types of reviews, descriptive and evaluative, coexisted. Upon looking at the reviewing strategies of the German orientalist Theodor Nöldeke and the experimental psychologist Wilhelm Wundt in the Literarisches Centralblatt, the main German review journal of the second half of the $19^{\text {th }}$ century, Engberts argues that reviewing was not only about addressing the author of the reviewed book, but was an important tool of community building. Thus, the reviews were not only guidelines on how to write in order to be acclaimed, but also how to write to be accepted as a part of the professional scholarly community in the first place.

The article by Richard Kremer (New Hampshire) and Ad Maas (Leiden) offers a study of the review practices in two prestigious journals on history of science, Isis and Journal for the History of Astronomy (JHA). By looking at the way that the reviews shifted over time, the authors show how these published in Isis remained more or less unchanged, while those published in $J H A$ changed from being dedicated to working astronomers and historians to being intended for specialized historians of astronomy. Similarly, the virtues, as Kremer and Maas

53 Habel 2005, p. 49. 
argue, are related closely to the intended readers, and reflect the increase of professionalization and specialization in the $20^{\text {th }}$ century.

In the closing article of this issue of Studia Historiae Scientiarum, Aleksei Lokhmatov (Cologne) looks at the discussion in Polish philosophy during the late Stalinism period, focusing on the socialist philosopher and sociologist, Adam Schaff, and his attempts to structure Polish scholarly communication according to the Soviet model. In this process, the reviews played a crucial role as a form of correction, aimed especially at the representatives of the Lvov-Warsaw school of philosophy. As Lokhmatov argues, Schaff's project failed, because his Soviet-based concepts, concerning the basic academic virtues, were incommensurable with the concepts of the majority of the Polish community of scholars.

\section{Financing of publication}

The article was prepared within the framework of the HSE University Basic Research Program.

\section{Bibliography}

Allen, Danielle S. 2004: Talking to Strangers: Anxieties of Citizenship since Brown v. Board of Education. Chicago: University of Chicago Press, 2004. ISBN: 9780226014678.

Agassi, Joseph 2017: The Place of Dichotomies in Western Philosophy. Lecture at the International Conference "Academic Revolutions?" Understanding conceptual renewal and institutional innovation in the Modern World," Poletayev Institute for Theoretical and Historical Studies in the Humanities National, Research University "Higher School of Economics," Moscow 12-13. October 2017. Available online (12 October 2017): https://www. youtube. $\mathrm{com} /$ watch? $\mathrm{v}=\mathrm{BKqkfNMaQO} 8 \& \mathrm{t}=10 \mathrm{~s}$.

Aristotle 2009: The Nicomachean Ethics. Translated by David Ross and Edited by Lesley Brown. Oxford: Oxford University Press. ISBN: 9780199213610.

Bilhartz, Terry D. 1984: In 500 Words or Less: Academic Book Reviewing in American History. The History Teacher 17(4), pp. 525-536.

Creyghton, Camille; Huistra, Pieter; Keymeulen, Sarah; Paul, Herman 2016: Virtue language in historical scholarship: the cases of Georg Waitz, Gabriel Monod and Henri Pirenne. History of European Ideas 42(7), pp. 924-936, DOI: 10.1080/01916599.2016.1161536 
Daston, Lorraine 1998: Academies and the unity of the sciences: disciplining the disciplines. Differences: a Journal of Feminist Cultural Studies 10(2), pp. 67-86.

Daston, Lorraine; Galison, Peter 2007: Objectivity. New York: Zone Books. ISBN: 9781890951795.

Daston, Lorraine; Sibum, Otto H. 2003: Introduction: Scientific Personae and Their Histories. Science in Context 16 (1/2), pp. 1-8. DOI: https://doi.org/ 10.1017/S026988970300067X.

Dhondt, Pieter (ed) 2011: National, Nordic or European? Nineteenth-Century University Jubilees and Nordic Cooperation. Leiden and Boston: Brill. ISBN: 978-90-0421694-5. DOI: https://doi.org/10.1163/9789004218307.

Dhondt, Pieter (ed) 2014: University Jubilees and University History Writing: a Challenging Relationship. Leiden and Boston: Brill. ISBN: 978-90-04-21696-9. DOI: https:// doi.org/10.1163/9789004265073.

Echterhölter, Anna 2012: Schattengefechte. Genealogische Praktiken in Nachrufen auf Naturwissenschaftler 1710-1860. [in German] Göttingen: Wallstein. ISBN: 9783835310711.

Engberts, Christiaan A. 2019: Conflicting virtues of scholarship : moral economies in late nineteenth-century German Academia. PhD Dissertation, Leiden University. Available online: https://hdl.handle.net/1887/81791.

Eskildsen, Kasper Risbjerg 2016: Scholarship as a Way of Life: Character and Virtue in the Age of Big Humanities. History of Humanities 1(2), pp. 387-397. DOI: https://doi.org/10.1086/687974.

Itakura, Hiroko; Tsui, Amy B.M. 2011: Evaluation in academic discourse: Managing criticism in Japanese and English book reviews. Journal of Pragmatics 43(5), pp. 1366-1379. DOI: https://doi.org/10.1016/i.pragma.2010.10.023.

Larrègue, Julien; Mongeon, Philippe; Warren, Jean-Philippe; Sugimoto, Cassidy R.; Larivière, Vincent 2019: Reciprocity in Book Reviewing among American, British and Canadian Academics. Canadian Journal of Sociology 44(1), pp. 95-114. DOI: $10.29173 /$ cjs29549.

Gael, Patricia 2012: The Origins of the Book Review in England, 1663-1749. Library 13 (1), pp. 63-89. DOI: https://doi.org/10.1093/library/13.1.63.

Galison, Peter 2008: Ten Problems in History and Philosophy of Science. Isis 99(1), pp. 111-124. DOI: https://doi.org/10.1086/587536.

Gelhard, Andreas; Hackler, Ruben; Zanetti, Sandro 2019: Einleitung. [In:] Epistemische Tugenden: Zur Geschichte und Gegenwart eines Konzepts. [in German] Edited by Andreas Gelhard, Ruben Hackler, Sandro Zanetti. Tübingen: Mohr Siebeck. ISBN 978-3-16-154072-1. DOI: https://doi.org/10.1628/978-3-16155463-6, pp. 1-8. 
Giddens, Anthony 1970: Durkheim as a Review Critic. The Sociological Review 18(2), pp. 171-196. DOI: https://doi.org/10.1111/j.1467-954X.1970.tb00189.x.

Gould, Thomas H. P. 2012: Do We Still Need Peer Review?: An Argument for Change. Lanham: Scarecrow Press. ISBN-13 : 978-0810885745

Habel, Thomas 2005: Deutschsprachige Rezensionszeitschriften der Aufklärung Zur Geschichte und Erschließung. [In:] Historische Presse und ibre Leser. Studien zu Zeitungen und Zeitschriften, Intelligenzblättern und Kalendern in Nordwestdeutschland. [in German] Edited by Peter Albrecht, Holger Böning. Bremen: Edition lumière. ISBN: 978-3934686236, pp. 42-77.

Hartley, James 2006: Reading and Writing Book Reviews Across the Disciplines. Journal of the American Society for Information Science and Technology 57(9), pp. 1194 -1207 .

Hadot, Pierre 2002: What is ancient philosophy? Cambridge, Mass: Harvard University Press, 2002. ISBN 9780674013735.

Hicks, Daniel J.; Stapleford Thomas A. 2016: The Virtues of Scientific Practice: MacIntyre, Virtue Ethics, and the Historiography of Science. Isis 107(3), pp. 449-472. DOI: https://doi.org/10.1086/688346.

Hursthouse, Rosalind; Pettigrove, Glen 2003: Virtue Ethics. Stanford Encyclopedia of Philosophy. Available online (18.06.2003): https://plato.stanford.edu/entries/ ethics-virtue/.

Krajewski, Markus 2016: Genauigkeit. Zur Ausbildung einer epistemischen Tugend im 'langen' 19. Jahrhundert. Berichte zur Wissenschaftsgeschichte 39(3), pp. 211-220. [in German]. DOI: https://doi.org/10.1002/bewi.201601772.

Kurennoy, Vitaly A. 2020: Philosophy of Liberal Education: The Principles. Voprosy obrazovaniya / Educational Studies Moscow 1, pp. 8-39.DOI: https://doi. org/10.17323/1814-9545-2020-1-8-39.

Lihackij Andrej A. 2018: Redakcionnaja politika i process recenzirovanija v zhurnale «Golos minuvshego» (nachalo XX veka). Novoe literaturnoe obozrenie 150(2), pp. 111-112. [in Russian].

Lihackij Andrej A. 2020: Recenzija v akademicheskih istoricheskih izdanijah konca XIX - nachala XX veka. [In:] Nauchnoe recenzirovanie v gumanitarnyh disciplinah. Zhanr, issledovanija, teksty. [in Russian] Edited by Aleksei Pleshkov, Natalja Dolgoroukova. Moscow: VShJe. ISBN: 978-5-7598-2127-4, pp. 90-109.

Lorenz-Meyer, Dagmar 2018: The Academic Productivist Regime: Affective Dynamics in the Moral-Political Economy of Publishing. Science as Culture, 27(2), pp. 151-174, DOI: https://doi.org/10.1080/09505431.2018.1455821.

Löffler, Karin (ed) 2020: Wissen in Bewegung. Gelehrte Journale, Debatten und der Buchhandel der Aufkelärung. [In German] Edited by Katrin. Stuttgart: Franz Steiner Verlag 2020. ISBN 978-3-515-12592-5. 
Matveev, Sergei R. 2018: «Uchenyj-bol'shevik prizvan ocenivat' obëktivno»: recenzii v sovetskoj istoricheskoj periodike 1930-1950-h godov. Novoe literaturnoe oborrenie 150(2), pp. 113-124. [in Russian]. DOI: https://doi.org/10. 17323/978-5-7598-2127-4.

Mosbah-Natanson, Sébastien 2008: Internationalisme et tradition nationale: le cas de la constitution de la sociologie française autour de 1900. Revue d Histoire des Sciences Humaines 18 (1), pp. 35-62. [In French]

Munck, Thomas 2010: Eighteenth-Century Review Journals and the Internationalization of the European Book Market. International History Review 32(3), pp. 415-35. https://doi.org/10.1080/07075332.2010.507343.

Nussbaum, Martha 1988: Non-Relative Virtues: An Aristotelian Approach. Midwest Studies in Philosophy 13(1), pp. 32-53. DOI: https://doi.org/10.1111/ j.1475-4975.1988.tb00111.x.

Orteza Y Miranda, Evelina 1996: On Book Reviewing. The Journal of Educational Thought (JET) / Revue De La Pensée Éducative 30 (2), pp. 191-202. Available online (October 31, 2020): http://www.jstor.org/stable/23768989.

Ottner, Christine 2014: The Professionalization of the Historical Discipline: Austrian Scholarly Periodicals, 1840-1900. [In:] The Making of the Humanities, Volume III. Edited by Rens Bod, Jaap Maat, Thijs Weststeijn. Amsterdam: Amsterdam University Press. ISBN: 9789048518449. DOI: https://doi. org/10.1515/9789048518449-011, pp. 157-170.

Paul, Herman 2019: Germanic Loyalty in Nineteenth-Century Historical Studies: A Multi-Layered Virtue. História da Historiografia 12(30), pp. 16-43. DOI: https://doi.org/10.15848/hh.v12i30.1476.

Paul, Herman 2011: Performing History: How Historical Scholarship is Shaped by Epistemic Virtues. History and Theory 50(1), pp. 1-19. DOI: https://doi. org/10.1111/j.1468-2303.2011.00565.x.

Paul, Herman 2014: What is a scholarly persona? Ten theses on virtues, skills, and desires. History and Theory 53, pp. 348-371. DOI: https://doi.org/10.1111/ hith.10717.

Paulitz, Tanja 2018: Objektive Distanz - subjektives Gefühl: Wissenschaftskultur, Geschlecht und die Praxis des Erkennens und Erfindens in den Technikwissenschaften. [In:] Epistemische Tugenden: Zur Geschichte und Gegenwart eines Konzepts. [In German] Edited by Andreas Gelhard, Ruben Hackler, Sandro Zanetti. Tübingen: Mohr Siebeck. ISBN 978-3-16-154072-1. DOI: https:// doi.org/10.1628/978-3-16-155463-6, pp. 121-134.

Päivi Oinas; Leppälä, Samuli 2013: Views on Book Reviews. Regional Studies 47(10), pp. 1785-1789. DOI: https://doi.org/10.1080/00343404.2013.856530. 
Plato 1987: Gorgias. Translated, with introduction and notes, by Donald J. Zeyl. Indianapolis: Hackett Pub. Co. ISBN: 0872200175.

Pleshkov, Aleksei; Surman, Jan 2020: Objectivity and Beyond: Interview with Lorraine Daston and Peter Galison, IQ: Research and Education Website. Available online: https://iq.hse.ru/en/news/397837371.html.

Pleshkov, Aleksei; Dolgoroukova, Natalja (eds.) 2020: Nauchnoe recenzirovanie v gumanitarnyh disciplinah. Zhanr, issledovanija, teksty. [in Russian] Moscow: VShJe. ISBN: 978-5-7598-2127-4. DOI: https://doi.org/10.17323/978-5-7598-2127-4.

Readings, Bill 1996: University in Ruins. Cambridge, MA; London: Harvard University Press. ISBN 9780674929531.

Schnicke, Falko 2015: Die männliche Disziplin. Zur Vergeschlechtlichung der deutschen Geschichtswissenschaft 1780-1900. [In German] Göttingen: Wallstein. ISBN 9783-8353-1756-7.

Shapin, Steven 2008: The Scientific Life: A Moral History of a Late Modern Vocation. Chicago: University of Chicago Press. ISBN: 9780226750248.

Stepanov, Boris E. 2016: «Krizis zhanra»: Knizhnye recenzii v perspektive issledovanij nauchnoj kommunikacii. Laboratorium. Zhurnal social'nyh issledovanij 1(8), pp. 82-106. [in Russian].

Stepanov, Boris E. 2020: Akademicheskie recenzii v obrazovatel'noj praktike i professional'noj samorefleksii. [In:] Nauchnoe recenzirovanie v gumanitarnyh disciplinah. Zhanr, issledovanija, teksty. Edited by Aleksei Pleshkov, Natalja Dolgoroukova. Moscow: VShJe. ISBN: 978-5-7598-2127-4, pp. 179-195. [in Russian].

Surman, Jan 2014: Divided Space - Divided Science? Closing and transcending scientific boundaries in Central Europe. [In:] Information beyond borders: international cultural and intellectual exchange in the Belle Époque. Edited by W. Boyd Rayward. Farnham, UK: Ashgate. ISBN 978-1-4094-4225-7, pp. 69-84.

Stöger, Alexander (2020): Epistemische Tugenden im deutschen und britischen Galvanismusdiskurs um 1800. Paderborn: Brill, Wilhelm Fink. [In German] ISBN: 978-3-7705-6548-1. DOI: https://doi.org/10.30965/9783846765487.

Topham, Jonathan R. 2013: Anthologizing the Book of Nature: The Circulation of Knowledge and the Origins of the Scientific Journal in Late Georgian Britain. [n:] The Circulation of Knowledge Between Britain, India and China: The Early Modern World to the Twentieth Century. Edited by Bernard Lightman, Gordon McOuat, Larry Stewart. Leiden: Brill Academic Publishers. ISBN: 9789004 251410. DOI: https://doi.org/10.1163/9789004251410 007, pp. 119-152.

Van Dongen, Jeroen; Paul, Herman 2017: Introduction: Epistemic Virtues in the Sciences and the Humanities. [n:] Epistemic Virtues in the Sciences and the 
Aleksei Pleshkov, Jan Surman

\section{Book reviews in the history of knowledge}

Humanities. Edited by Jeroen van Dongen, Herman Paul. Cham, Switzerland: Springer. ISBN: 978-3-319-48892-9, pp. 1-10.

Wang, Dongmei; An, Xuehua 2013: A Study of Appraisal in Chinese Academic Book Reviews. Journal of Language Teaching and Research 4(6), pp. 1247-1252. DOI: https://doi.org/10.4304/iltr.4.6.1247-1252.

Wald Valensky, Sandra 2010: Composition Under Review: A Genre Analysis of Book Reviews In Composition, 1939-2007. PhD Dissertation, Wayne State University. Available online: https://digitalcommons.wayne.edu/oa_dissertations/134/.

Wilholt, Torsten 2012: Die Freiheit der Forschung - Begründungen und Begrenzungen. Berlin: Suhrkamp. ISBN: 978-3-518-29640-0. [In German]. 